\title{
ENTREPRENEURIAL ACTION AND THE ROLE OF UNCERTAINTY IN THE THEORY OF THE ENTREPRENEUR
}

\author{
JEFFERY S. MCMULLEN \\ Baylor University \\ DEAN A. SHEPHERD \\ Indiana University
}

\begin{abstract}
By considering the amount of uncertainty perceived and the willingness to bear uncertainty concomitantly, we provide a more complete conceptual model of entrepreneurial action that allows for examination of entrepreneurial action at the individual level of analysis while remaining consistent with a rich legacy of system-level theories of the entrepreneur. Our model not only exposes limitations of existing theories of entrepreneurial action but also contributes to a deeper understanding of important conceptual issues, such as the nature of opportunity and the potential for philosophical reconciliation among entrepreneurship scholars.
\end{abstract}

Entrepreneurship requires action. Whether conceptualized as the creation of new products or processes (Schumpeter, 1934), entry into new markets (Lumpkin \& Dess, 1996), or the creation of new ventures (Gartner, 1985), entrepreneurship typically involves a mesolevel phenomenon in which personal initiative influences system-wide activity and outcomes (Kilby, 1971; Stevenson \& Jarillo, 1990). To be an entrepreneur, therefore, is to act on the possibility that one has identified an opportunity worth pursuing.

Theories of entrepreneurship that embrace this perspective traditionally have taken one of two forms. The first form is devoted to a systemlevel approach concerned primarily with how the economic system functions. Proponents of these theories argue that the health of the economy depends on the pursuit of opportunities by prospective entrepreneurs (e.g., Kirzner, 1973; Schumpeter, 1934). Who acts is inconsequential as long as someone does. Thus, the central issue is whether entrepreneurial action occurs. The second form is devoted to an individual-level approach concerned primarily with how prospective entrepreneurs go about acting. These researchers seek to explain why some individuals are more likely than others to pursue possi-

We acknowledge Jeff Covin, Denis Gregoire, Duane Ireland, P. Devereaux Jennings, and three anonymous reviewers for their valuable comments on an earlier draft of this paper. ble opportunities for profit (e.g., Begley \& Boyd, 1987; Sarasvathy, 200la; Shane, 2000; Shaver \& Scott, 1991). Like before, entrepreneurial action takes center stage, but this time more in terms of how it occurs and who does it than whether it occurs.

The conceptual overlap of these approaches suggests that they are complementary. In fact, researchers of the individual-level approach have frequently borrowed from theories grounded in the system-level approach (e.g., Kaish \& Gilad, 1991). However, this can lead scholars to rely on models of entrepreneurial action that are incomplete when applied at a level of analysis other than that intended by the theorist. Accordingly, our purpose in this article is twofold. First, we demonstrate that economic theories of the entrepreneur are theories of action proposing those elements that enhance and hinder individuals from acting entrepreneurially. Although these models may be sufficient for examining entrepreneurial action at the system level, they can collapse when applied at the individual level, making them susceptible to confounded theorizing and inconclusive or misleading empirical findings. This necessitates our second purpose: to offer a perspective that allows for examination of entrepreneurial action at the individual level of analysis while remaining consistent with a rich legacy of systemlevel theories of the entrepreneur.

Because action takes place over time, and because the future is unknowable, action is inher- 
ently uncertain (Mises, 1949). This uncertainty is further enhanced by the novelty intrinsic to entrepreneurial actions (Amabile, 1997; Smith \& DiGregorio, 2002), such as the creation of new products, new services, new ventures, and so forth (Gartner, 1990; Schumpeter, 1934). Therefore, it is no surprise that uncertainty constitutes a conceptual cornerstone for most theories of the entrepreneur. However, the role this uncertainty plays in preventing entrepreneurial action has remained a matter of debate. As a result, two research streams have emerged, each inspired by alternative conceptualizations of uncertainty.

The first stream focuses on the amount of uncertainty perceived and frequently discriminates those who decide to act entrepreneurially from those who do not as a matter of differences in knowledge (e.g., Busenitz, 1996; Gaglio \& Katz, 2001; Kaish \& Gilad, 1991; Kirzner, 1979). Thus, the amount of uncertainty is considered to be the barrier between prospective entrepreneurs and entrepreneurial action. The second stream highlights the willingness to bear uncertainty and typically proposes that those who decide to act entrepreneurially are distinguishable from those who do not owing to differences in motivation, attitude, or risk propensity (e.g., Douglas \& Shepherd, 2000; Knight, 1921; Schumpeter, 1934). In this scenario, an unwillingness to bear uncertainty is deemed responsible for preventing prospective entrepreneurs from engaging in entrepreneurial action.

Because an individual must ultimately act to become an entrepreneur, and because action involves knowledge and motivation (Higgins \& Kruglanski, 2000), we propose that each stream merely emphasizes a different aspect of the uncertainty experienced in the decision to act entrepreneurially. Therefore, each conceptualization of uncertainty is representative of a construct that is not only reconcilable with its counterpart but also necessary for further theorizing about entrepreneurial action.

By demonstrating that action is central to most theories of entrepreneurship, we distill the various elements of action that must be considered concomitantly when determining whether one will act entrepreneurially. These include knowledge (as it relates to the amount of uncertainty perceived), motivation (as it relates to the willingness to bear uncertainty), and, arguably, a stimulus. We propose that each of these elements produces a belief that is qualified by un- certainty. This uncertainty takes the form of doubt, which prevents action by undermining the prospective actor's beliefs regarding (1) whether an environmental stimulus presents an opportunity for someone in the marketplace, (2) whether this opportunity could feasibly be enacted by the actor, and (3) whether successful exploitation of the opportunity would adequately fulfill some personal desire. Drawing on these elements, we then generate a two-stage conceptual model of entrepreneurial action that makes an important distinction between thirdperson opportunity (an opportunity for someone) and first-person opportunity (an opportunity for the actor) while explicitly recognizing that both knowledge and motivation must be considered concomitantly when examining entrepreneurial action in each stage.

This article makes a number of contributions identified by Whetten (1989) as important theoretical insights. First, we use epistemological evidence from the philosophy and psychology of action literature to demonstrate that the entrepreneurship literature is characterized by onedimensional conceptualizations of uncertainty's preventive role in the entrepreneurial action process. Second, we offer a conceptual model of entrepreneurial action that demonstrates how the addition of a new construct (in some cases motivation and in others knowledge) significantly alters our understanding of the role that uncertainty plays in preventing entrepreneurial action. Third, we use the proposed model to reinterpret theories of the entrepreneur, thereby enhancing these highly influential economic models' predictive validity of entrepreneurial action at the individual level. Fourth, we use the model to reveal points of empirical tractability and philosophical impasse between entrepreneurship theorists employing different ontological assumptions regarding opportunity. Finally, we offer a pragmatic and a conceptual approach to the difficult task of reconciling contentious philosophical perspectives.

The article proceeds as follows. First, we explore the notions of the entrepreneur and entrepreneurial action that highlight the importance of judgment under uncertainty, and then acknowledge the role of belief and doubt in entrepreneurial judgment using a discussion involving three types of uncertainty: state, effect, and response. Second, we introduce a number of theories of the entrepreneur and classify them in 
terms of two streams of research on uncertainty: one stream emphasizes the role of perceived uncertainty and the second gives prominence to the willingness to bear uncertainty. Third, we offer a conceptual model of entrepreneurial action that reconciles aspects of the two streams of research that have previously remained independent of each other. We describe our conceptual model of entrepreneurial action as the outcome of the willingness to bear perceived uncertainty. Fourth, we use our proposed conceptual model of entrepreneurial action to reinterpret three economic theories of the entrepreneur that are considered to be most influential to the management literature. Finally, we cannot avoid a discussion of the "thorny" issue of ontology. In this section we discuss a number of different perspectives about the existence of an objective opportunity and propose two potential approaches for reconciling apparently contrasting views.

\section{ENTREPRENEURIAL ACTION AND UNCERTAINTY}

Because we are interested in the entrepreneur as an organizational or economic function that is filled by an individual, rather than as a personality (i.e., innovative, risk seeking, etc.) or position (i.e., small business manager, owner, etc.), we seek definitional foundation in economics, where the entrepreneur traditionally has been conceptualized in this manner (Casson, 1982: 22). After surveying economic theory devoted to entrepreneurship, Hebert and Link attempt to synthesize several theoretical profiles by defining the entrepreneur as "someone who specializes in taking responsibility for and making judgmental decisions that affect the location, the form, and the use of goods, resources or institutions" (1988: 155). They openly admit their definition's similarity to that proposed by Mark Casson, who defines an entrepreneur as "someone who specializes in taking judgemental decisions about the coordination of scarce resources" (1982: 23). Interestingly, both of these definitions are reminiscent of the first theory of the entrepreneur put forth by Richard Cantillon in 1755 , in which he defined the entrepreneur as "someone who engages in exchanges for profit; specifically, he or she is someone who exercises business judgment in the face of uncertainty" (quoted in Hebert \& Link, 1988: 21).
Each of these definitions suggests that the entrepreneur is an individual who exercises judgment, which Hastie defines as "the components of the larger decision-making process that are concerned with assessing, estimating, and inferring what events will occur and what the decision-maker's evaluative reactions to those outcomes will be" (2001: 657). "Decision making," he adds, "refers to the entire process of choosing a course of action" (2001: 657). Finally, Hastie suggests that uncertainty refers to "the decisionmaker's judgments of the propensity for each of the conditioning events to occur" (2001: 657). Therefore, judgment is what must be exercised to make a decision between alternative courses of action that take place in an uncertain future.

Although many scholars have emphasized the individual's exercising of judgment under uncertainty in the form of a decision (e.g., Cantillon, Cole, Keynes, Marshall, Menger, Schultz, Shackle, etc.), it is important to note that a decision is a necessary but insufficient condition for the occurrence of entrepreneurship. We return to the basic realization that entrepreneurship requires one not just to decide but to decide to act. Therefore, we subscribe to Hebert and Link's (1988) position that entrepreneurs respond to and create change through their entrepreneurial actions, where entrepreneurial action refers to behavior in response to a judgmental decision under uncertainty about a possible opportunity for profit. ${ }^{1}$ Whether entrepreneurial action occurs, however, depends on how much one must rely on one's judgment, which, in turn, depends on the degree of uncertainty experienced in the decision of whether to act.

Alternative conceptualizations of uncertainty exist within the management, economics, and psychology literature. Particularly noteworthy is Milliken's (1987) exposure of conceptual inconsistencies of the term within the organizational literature. As a result, he proposes three distinct types of uncertainty (state, effect, and response) that appear to be as applicable to the individual

\footnotetext{
${ }^{1}$ This conceptualization of entrepreneurial action is process oriented and transferable across a range of different definitions of entrepreneurship within the management literature (e.g., Gartner, 1990; Shane \& Venkataraman, 2000). These scholars identify specific behaviors that are thought to be especially "entrepreneurial" in nature, such as new venture creation or Schumpeter's (1934: 66) five forms of new combinations.
} 
as they are to the organization as a unit of analysis. Milliken suggests that state uncertainty is used to denote when administrators perceive the environment to be unpredictable (1987: 136). In contrast, effect uncertainty is defined as "an inability to predict what the nature of the impact of a future state of the environment or environmental change will be to the organization" (1987: 137). Finally, Milliken suggests that response uncertainty is "a lack of knowledge of response options and/or an inability to predict the likely consequences of a response choice (Conrath, 1967; Duncan, 1972; Taylor, 1984)" (1987: 137), and he further points out that "response uncertainty is likely to be salient when there is a perceived need to act... because a pending event or change is perceived to pose a threat or to provide some unique opportunity to the organization" (1987: 137).

Milliken's framework implies that uncertainty in the context of action falls within the exclusive domain of response uncertainty. However, this perceived need to act frequently is stimulated by state or effect uncertainty. This would suggest that, in the context of action, Milliken's three types of uncertainty could be simplified into three questions asked by a prospective actor about his or her relationship to the environment: (1) What's happening out there? (state uncertainty), (2) How will it impact me? (effect uncertainty), and (3) What am I going to do about it? (response uncertainty).

Questions like these require one to form a belief, defined as a "conviction that certain things are true" (Neufeldt \& Sparks, 1995: 55). However, this belief is often qualified by a related sense of doubt, which means "to be uncertain or undecided; to tend to disbelieve" (Neufeldt \& Sparks, 1995: 180). This process, in which a belief and a related sense of doubt are formed, presupposes the existence of a world that is malleable and somewhat susceptible to beneficial actor influence. Therefore, it communicates a world view that is neither fully determined nor fully random (Moya, 1990; Shackle, 1966), and, as a consequence, "uncertainty" can be viewed as a sense of "doubt" that is inextricable from the beliefs that produce action.

Therefore, because we are interested in the role that uncertainty plays in preventing people from acting entrepreneurially, we embrace the proposition made by Lipshitz and Strauss that "uncertainty in the context of action is a sense of doubt that blocks or delays action" (1997: 150). This conceptualization captures three essential features of uncertainty integral to our argument. First, the proposition suggests that uncertainty is subjective in that "different individuals may experience different doubts in identical situations" (Lipshitz \& Strauss, 1997: 150; see also Duncan, 1972). Lipshitz and Strauss (1997) point out that the conceptualization of uncertainty as a subjective experience has a long tradition within psychology (Duncan, 1972; Smithson, 1989). Entrepreneurship enthusiasts have contributed to this tradition (1) by assuming that uncertainty prevents action (Shane \& Venkataraman, 2000; Stevenson \& Jarillo, 1990) and (2) by attributing variation in its action-obstructive nature to individual differences in needs (McClelland, 1961), values (Weber, 1930), attitudes toward risk (Khilstrom \& Laffont, 1979), confidence (Cooper, Woo, \& Dunkelberg, 1988), perceptions (Palich \& Bagby, 1995), and heuristics (Busenitz \& Barney, 1997).

The second and third features of Lipshitz and Strauss's uncertainty proposition are that it is inclusive in that no particular form of doubt is specified, such as ignorance of future outcomes (Conrath, 1967; Smithson, 1989), and that it is conceptualized in terms of the effect of uncertainty on action - that is, hesitancy, indecisiveness, and procrastination (Dewey, 1933; Goldman, 1986; March, 1981; Yates \& Stone, 1992). These last two features serve to define uncertainty more in terms of what it does than what it is. This diminishes the importance of determining which of Milliken's (1987) three forms of environmental uncertainty is technically being discussed, because each prevents action by contributing to doubt. Likewise, whether conceptualized as risk (MacCrimmon \& Wehrung, 1986), Knightian uncertainty (Knight, 1921), ambiguity (Hogarth, 1987; March \& Olsen, 1976), turbulence (Terreberry, 1968), or equivocality (Weick, 1979), uncertainty in the context of action acts as a sense of doubt that (1) produces hesitancy by interrupting routine action (Dewey, 1933), (2) promotes indecision by perpetuating continued competition among alternatives (Goldman, 1986), and (3) encourages procrastination by making prospective options less appealing (Yates \& Stone, 1992).

Entrepreneurship theorists have embraced the position that uncertainty is detrimental to entrepreneurial action because properties such 
as hesitancy, indecisiveness, and procrastination are thought to lead to missed opportunities (Casson, 1982). The opportunity for action is often conceptualized as fleeting (James, 2002; Shane \& Venkataraman, 2000), owing to the competitive nature of the market process (Mises, 1949; Schumpeter, 1942). This position is grounded in an economic assumption that the procrastination of one actor is typically offset by the profit-seeking proactiveness of others (Mann, 1996). Thus, economists often consider it inevitable that someone in the marketplace will act, which makes the decision process experienced by any one individual seemingly inconsequential (Stigler, 1963).

Despite economists' system-level, probabilistic perspective of entrepreneurial action, however, we wish to point out that there is no market independent of the actors who create it. Therefore, ultimately, someone somewhere must undergo a decision process in which action is chosen if any market "process" is to occur. Overlooking this fact has arguably contributed to the generation of alternative theories of the entrepreneur characterized by examination of only one dimension of uncertainty's effect on action.

\section{ALTERNATIVE THEORIES OF THE ENTREPRENEUR}

Traditionally, the label theory of the entrepreneur has been used within the economics literature to denote the study of the relationship between entrepreneurship and economic activity. These theories (e.g., Kirzner, 1973; Knight, 1921; Schumpeter, 1934) frequently attribute the movement of the economy to a catalystic function fulfilled by the entrepreneur. Accordingly, the entrepreneur is conceptualized in terms of what he or she does-that is, innovates, coordinates, etc. This behavior is then thought to influence the system by moving it toward, or away from, some ideal state, such as equilibrium or efficiency.

Two assumptions are characteristic of most theories of the entrepreneur: (1) entrepreneurship is a "good" thing, with beneficial outcomes that accrue to the system in which it occurs (Kilby, 1971; Stevenson \& Jarillo, 1990), ${ }^{2}$ and (2)

\footnotetext{
${ }^{2}$ Baumol (1996) questions this assumption by suggesting that entrepreneurs pursue profit. If this profit is achieved via
}

entrepreneurship is observable as a behavior that can be attributed to some definitive theoretical attribute capable of differentiating entrepreneur (actor) from nonentrepreneur (nonactor). Although the first assumption is important for understanding why scholars have devoted so much energy to the subject and why the study of entrepreneurial behavior at the individual level is of value to organizational studies, it is not the focal point of this article. The second assumption, however, is highly significant to our argument in that it helps to expose the manner in which uncertainty is conceptualized within these theories.

We suggest that many theoretical explanations of why prospective entrepreneurs choose to pursue a possible opportunity can be classified into two simple conceptualizations of the role that uncertainty plays in preventing action: (1) the amount of uncertainty perceived and (2) the willingness to bear uncertainty. We turn now to a deeper examination of each.

\section{Entrepreneurial Action As the Outcome of Less Perceived Uncertainty}

While neoclassical economists were abolishing the need to consider individual differences by constructing theories with assumptions such as perfect information, "Austrian" economists were building their economic theories on such premises as the subjectivity of value (Menger, 1950), imperfect knowledge (Hayek, 1945), asymmetric beliefs (Mises, 1949), and differences in entrepreneurial alertness (Kirzner, 1973, 1985). Austrian economists typically have considered the entrepreneur to be the engine of the economy (Kirzner, 1989; Mises, 1949; Pasour, 1989) and have attributed the stagnation of the economy to a lack of entrepreneurial action. This lack of entrepreneurial action, they believe, is often the consequence of unperceived opportunities (Kirzner, 1979), which arise from the various explanations mentioned above.

Although Austrians are labeled subjectivists, this subjectivism traditionally has referred to the epistemological limitations suffered, to a greater or lesser extent, by the subjects of their

innovation, then the system benefits as a by-product. However, if innovation is difficult or unnecessary for profit, then entrepreneurial energy is likely to take unproductive or even destructive forms. 


\section{A Psychological Approach to Entrepreneurship}

theories. Thus, people who have acted entrepreneurially are seen to possess a more accurate picture of reality than those individuals who have not acted. Moreover, an objective reality is thought to exist in which a market opportunity is there for the taking, but only for those who possess the qualities necessary both to discover and exploit it (see Addleson, 1995, for an eloquent articulation of this point). Thus, entrepreneurial action is seen as something all would engage in if they knew what to do, but, owing to epistemological differences, only some people (the entrepreneurs) "know" what to do. Accordingly, entrepreneurs are thought to have taken action because they somehow escaped the ignorance and paralysis produced by uncertainty, whereas those who have not acted entrepreneurially are believed either to have fallen victim to doubt or to have been blinded to the need for forming a belief at all.

Graphically, this can be depicted as in Figure 1. This figure shows two hypothetical internal response curves centered around two means. ${ }^{3}$ The left mean represents the noisy status quo,

\footnotetext{
${ }^{3}$ The curves centered around the two means are representative of hypothetical responses to the question of whether the individual believes that a third-person opportunity exists. If the answer is no, then the decision would reflect a point on the left curve, whereas if the answer is yes, then the decision would reflect $\alpha$ point on the right curve. Under a repeated decision scenario, such as those conducted in experimental settings, this process would produce a response curve around each mean composed of points representing actual decisions. However, we qualify the curves as "hypothetical" because, in a natural context, only one point of an individual's response curve is observable.
}

and the right mean represents third-person opportunity, which we define as a potential opportunity for someone in the marketplace. Thus, third-person opportunity may not reflect an opportunity for everyone, but, for those individuals with the right qualities, market potential exists. The distance between the means signifies the ability to discern the market potential of this third-person opportunity. For example, one would expect the market potential of a teleporter to be more easily discerned than, say, the market potential of the internet prior to web browsers.

The distance between the means and the distribution of the curves contribute to the amount of uncertainty perceived in the decision to act. Although the Austrian presumption of an objective reality suggests that the distance between the means is the same for any prospective actor, the distribution of the curves surrounding these means frequently is discussed as a function of a theoretically determined individual difference. For example, according to Hayek's (1945) argument, considerable overlap between the two curves would represent an individual with little "local" knowledge of time and place, whereas little overlap would reflect an individual with a knowledge base that is highly applicable to the recognition and exploitation of this particular third-person opportunity. Thus, the discriminating feature between these two individuals is the possession of applicable knowledge. This knowledge reduces perceived uncertainty to a point that not only enables prospective entrepreneurs to form a belief that they have recog-

FIGURE 1

\section{Hypothetical Internal Response Curves Regarding Third-Person Opportunity}

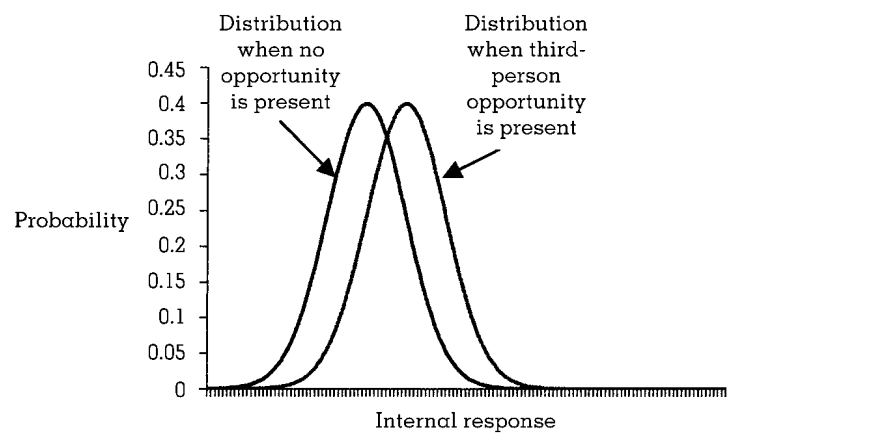


nized a third-person opportunity but also allows them to overcome the belief-related doubt that would otherwise prevent action.

Therefore, according to many theories of entrepreneurial action, uncertainty has been conceptualized in terms of quantity. Owing to the distance between the means and the distribution around the means, the prospective entrepreneur is thought to face more or less uncertainty, which prevents action either by obfuscating the existence of the third-person opportunity or by contributing to the doubt people experience in their belief that a third-person opportunity exists. Thus, the uncertainty perceived by a prospective actor forms a continuum, with complete ignorance on one end (denoted graphically as flat response curves) to near certainty on the other end (denoted graphically as response curves that nearly form a perfectly straight perpendicular line at the mean, with no overlap between these narrow curves). Although the role that perceived uncertainty plays in obstructing entrepreneurial action is important, we argue that it is insufficiently explanatory, because it says nothing about the willingness to bear the uncertainty that is perceived.

\section{Entrepreneurial Action Ass the Outcome of More Willingness to Bear Uncertainty}

The theory of the entrepreneur is not the exclusive domain of the Austrian economist. Prominent non-Austrians, from Knight (1921) to Schumpeter (1934), also have recognized the role that uncertainty plays in preventing entrepreneurial action. However, these economic theorists conceptualize uncertainty's action prohibitive role in a slightly different way. They see entrepreneurial action not as the outcome of less perceived uncertainty but as more willingness to bear the uncertainty faced by all prospective actors. For instance, Knight addresses uncertainty explicitly. He posits that profit is the reward for those willing to bear uncertainty because, unlike risk, uncertainty is inestimable and therefore uninsurable. Thus, entrepreneurs are distinguishable from nonentrepreneurs in their willingness to bear the uncertainty intrinsic to a possibly profitable course of action.

In contrast, the willingness to bear uncertainty is implicit in Schumpeter's theory, where he argues that the entrepreneur's function lies in the innovative act of creating new combina- tions. Believing that the potential for new combinations is abundant and at times obvious, Schumpeter delineates entrepreneurs from nonentrepreneurs not by differences in knowledge or perception but by the performance of the innovative act itself (1934: 88). This elimination of perceptual differences forces Schumpeter to speculate reluctantly about motivational differences in an attempt to explain why some individuals and not others engage in entrepreneurial action (1934: 90).

Schumpeter's (1934) behavioral bent attracted psychologists, such as McClelland (1961), Hagen (1962), and Kunkel (1965), who exchanged the economic theorists' descriptive orientation for a more prescriptive theoretical viewpoint. Whereas economic theories of the entrepreneur focused on explaining what must occur (e.g., uncertainty bearing) for the economy to function, psychological theories sought to explain why entrepreneurs are more willing than their counterparts to bear this uncertainty. Because these psychologists shared the economists' belief that entrepreneurship produced economic growth, they tried to identify the motives underlying entrepreneurial activity in an effort to develop these motives in their subjects. Unfortunately, this was thought to produce explanations that relied too heavily on unchangeable needs and values developed in childhood. ${ }^{4}$

Graphically, this can be depicted as in Figure 2. Figure 2 builds on the graph shown in Figure 1. However, in this case, the distance between the means and the distribution of the curves remain constant. The vertical line in Figure 2 indicates the criterion, used to designate the point at which the prospective entrepreneur is willing to act. It is at this point that the prospective entrepreneur decides that a possible thirdperson opportunity is an opportunity for him or her-that is, a first-person opportunity. The criterion, therefore, conveys the individual's willingness to bear the uncertainty intrinsic to entrepreneurial action.

A criterion that splits the uncertainty (denoted by the area of the overlapping response curves)

\footnotetext{
${ }^{4}$ It should be noted that, unlike critics, these theorists did not see these motives as unchangeable elements of personality. For instance, much of McClelland's empirical work was devoted to establishing that the need for achievement could be learned. We wish to thank Jerry Katz for this insightful observation.
} 
FIGURE 2

The Criterion As the Individual's Willingness to Bear Uncertainty Intrinsic to Entrepreneurial Action

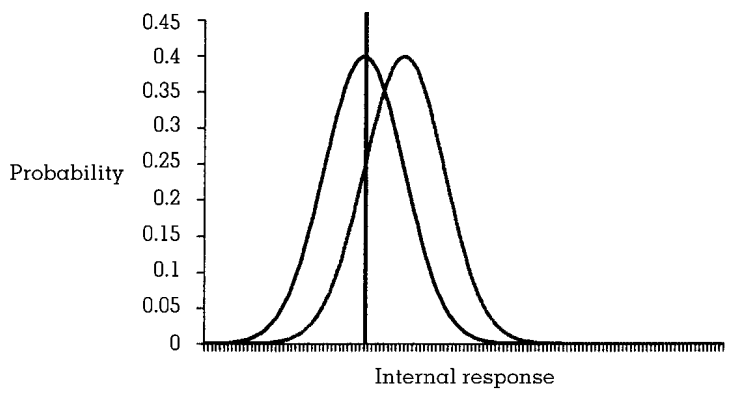

in half means that a prospective actor will be as likely to act as not. In contrast, if an individual chooses a lax criterion (denoted by moving the criterion to the left), he or she will pursue almost every possibility that comes along. Such a location of the criterion is representative of the profile of the Schumpeterion entrepreneur who is frequently conceptualized as an innovator, leader, and/or adventurer. It is also reflective of the Knightion entrepreneur who is explicitly conceptualized as a "bearer of uncertainty." Psychologists like McClelland sought to explain the "laxity" of the criterion (e.g., as the need for achievement) and promote it in an effort to encourage entrepreneurial activity.

If the individual chooses a strict criterion (denoted by moving the criterion to the right), he or she will choose to pursue very few possibilities. Given the uncertainty surrounding the decision, there is always overlap between the noise and third-person opportunity curves. Thus, individuals are forced to expose themselves to the possibility of either committing an error of commission (taking action only to find their belief was unfounded) or committing an error of omission (not taking action only to regret it when time proves that their passed-over hunch was correct). Although only time proves prophecy, consideration of the possible payoffs associated with these various decisional outcomes shapes prospective actors' decisions as they contemplate whether to commit to a particular course of action.

A simple amalgamation of the above arguments suggests that uncertainty prevents action by obfuscating (1) the need or possibility for action, (2) the knowledge of what to do, ${ }^{5}$ and (3) whether the potential reward of action is worth the potential cost. In the next section we present a conceptual model (illustrated in Figure 3 ) that relates perceived uncertainty and motivation to entrepreneurial action.

\section{A PROPOSED SYNTHESIS: ENTREPRENEURIAL ACTION AS THE OUTCOME OF THE WILLINGNESS TO BEAR PERCEIVED UNCERTAINTY}

Environmental change is usually thought to be a source of business opportunities. For example, Shane (2000) investigated a technological change in printing ( $\alpha$ patented three-dimensional printing process) and eight teams of entrepreneurs, each of whom pursued a different opportunity arising from the technology. Similarly, we use technological change as a starting point to summarize our conceptualization of the two stages of entrepreneurial action.

\section{Stage I: Attention and Third-Person Opportunity}

Stage I addresses first-person attention. Either people acknowledge $a$ third-person opportunity arising from a technological change or they do not. Of course, those individuals who are unaware of the technological change are likely to

${ }^{5}$ We use "what to do" inclusively. That is, "what to do" does not refer merely to the "end" but also to the "means" of "how," "when," and "where" that end is to be achieved. 
FIGURE 3

A Conceptual Model Relating Perceived Uncertainty and Motivation to Entrepreneurial Action

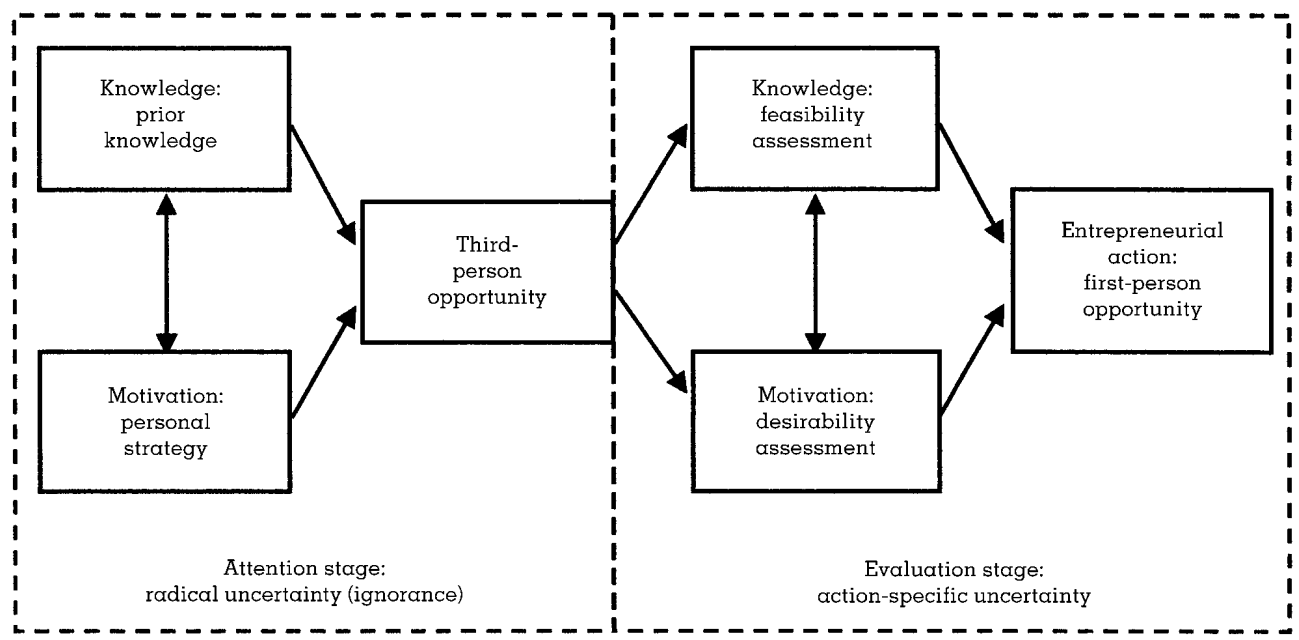

fall into the latter category. For example, without a certain degree of domain-specific knowledge, one may not even recognize the possibility for action (by oneself or others). In other words, there may be so much uncertainty that the individual is too ignorant to ask, "What's happening out there?" Thus, whether individuals perceive Milliken's state and effect uncertainty depends on whether they know enough about a technological change to perceive it, even if only faintly. This suggests that a general form of domainspecific knowledge is necessary to trigger the experiencing of response uncertainty.

However, knowledge need not predicate motivation in this process. Before the criterion becomes attached to the evaluation of a particular third-person opportunity, its location depends on an individual's strategy. "A strategy refers to a pattern of decisions in the acquisition, retention, and utilization of information that serves to meet certain objectives, i.e., to insure certain forms of outcome and to insure against certain others" (Bruner, Goodnow, \& Austin, 1956: 54). Thus, the position of the criterion prior to the existence of a stimulus represents the individual's strategy.

For example, when a person becomes dissatisfied with his or her current athletic shoes, the individual may begin to consider switching brands when buying a new pair. As a consequence, the individual will likely become more sensitive to what others are wearing than before and will increasingly allocate attention to the issue. This relaxes the criterion, making the individual more sensitive to his or her environment. This can produce deliberate search, such as exploring various stores in the hopes of finding the qualities the person is looking for in on athletic shoe (e.g., improved performance and comfort, through reduction of the accumulation of sweat in the shoe), or it can take form as a discovery heuristic (Gigerenzer, 1991), such as a sudden increase in awareness of ventilation technology used in other products (e.g., bellows, fans, suction devices) that one (and others) had previously ignored. Either way, the desire for a new, improved athletic shoe has spurred the acquisition of knowledge likely to prompt the recognition of recent technological advances in fan miniaturization (for use in computers) and the determination that to insert miniaturized fans in athletic shoes represents a third-person opportunity, one that reduces the temperature of the foot and thus reduces sweating, odor, and such fungal infections as athlete's foot. Once that opportunity is noticed, however, the criterion becomes attached to the specific action nec- 
essary to assess whether third-person opportunity represents first-person opportunity.

Therefore, the acknowledgment of a thirdperson opportunity arising from a technological change is configural in the sense that people who have the necessary knowledge and motivation will believe that there is third-person opportunity arising from a technological change, but those who do not have the necessary knowledge and motivation will not believe that the technological change represents an opportunity for someone and will no longer attend to it. Stage II applies only to those individuals who believe that a third-person opportunity exists.

\section{Stage II: Evaluation and First-Person Opportunity}

Stage II addresses first-person evaluation. The belief that a technological change represents a third-person opportunity triggers a decision-making process in which the prospective entrepreneur must evaluate whether this thirdperson opportunity constitutes a first-person opportunity. The individual forms beliefs regarding what to do and why to do it-that is, whether the potential reward for this particular action is worth the potential cost specific to oneself. However, both of these beliefs are undermined to a greater or lesser extent by doubt. Therefore, regardless of whether the construct of knowledge or motivation is discussed, the process remains the same: a belief is formed regarding a desired end state, but doubt exists regarding whether that desired end state is feasible (can be achieved in the manner envisioned) and desirable (whether its attainment will fulfill the motive for which it is being sought). ${ }^{6}$

This evaluation stage is rooted in Aristotle's "practical syllogism," which forms the foundation of most expectancy-value theories (e.g., Ajzen, 1996a,b; Gatewood, Shaver, Powers, \& Gartner, 2002). According to Aristotle (1987), the premises of this syllogism are the actor's desires ("A wants to achieve $X^{\prime \prime}$ ) and beliefs ("A believes that if $B$ is performed $X$ will occur"), and the conclusion is not another belief but the action itself. Thus, the realization that individual ac-

\footnotetext{
${ }^{6}$ See Barnard (1968) for an analogous argument in which the terms effectiveness and efficiency are used, respectively, to delineate goal attainment from motive satisfaction.
}

tion is not solely a function of knowledge or motivation but, rather, a composite of belief and desire regarding a particular form of behavior is not new, nor is it limited to expectancy-value theory (Greve, 2001). In fact, Hastie suggests that the field of judgment and decision making is about "how people ... combine desires (utilities, personal values, goals, ends, etc.) and beliefs (expectations, knowledge, means, etc.) to choose a course of action" (2001: 655-656). He goes on to point out that the conceptual and perhaps defining template for a decision comprises three components:

(a) courses of action (choice, options, and alternatives); (b) beliefs about objective states, processes, and events in the world (including outcome states and means to achieve them); and (c) desires, values, or utilities that describe the consequences associated with the outcomes of each action-event combination (2001: 656).

Believing that one has recognized a thirdperson opportunity does not necessarily mean one believes one possesses the knowledge and motivation necessary to exploit it. However, through learning efforts and/or the encouragement of others, one may be able to overcome doubt and act. Therefore, the question of the second stage is similar to a classic "risk/return" dilemma in which a prospective actor must ask him/herself whether he or she believes that the payoff of the third-person opportunity justifies bearing the perceived uncertainty necessary to attain it. If the answer is yes, then a first-person opportunity is believed to exist, and entrepreneurial action takes place. The "risk" of this risk/return dilemma, however, is subjectively determined by the prospective actor. Thus, it seems that, to act entrepreneurially, people need not have a high tolerance for uncertainty if they believe that they know what they are doing.

Therefore, whether one will engage in a particular action is a decision that depends on whether the individual is motivated enough to act, given the uncertainty he or she expects to encounter in pursuit of a third-person opportunity. The next section applies our model to $a$ number of influential economic theories of the entrepreneur (conveyed in Table 1) not only as a means of revealing problems that management scholars face when trying to apply these theories of the entrepreneur to the individual rather than system level, but also as a means of glean- 
TABLE 1

Limitations and Assumptions of Three Influential Theories of the Entrepreneur

\begin{tabular}{|c|c|c|c|c|}
\hline Theorist & $\begin{array}{l}\text { Knowledge: } \\
\text { Perceived } \\
\text { Uncertainty }\end{array}$ & $\begin{array}{l}\text { Motivation: } \\
\text { Willingness to } \\
\text { Bear Uncertainty }\end{array}$ & $\begin{array}{l}\text { Philosophical } \\
\text { Stance }\end{array}$ & Importance of Configural Argument \\
\hline Schumpeter & Relatively ignored & $\begin{array}{l}\text { Addressed-primarily } \\
\text { in terms of the } \\
\text { evaluation } \\
\text { stage }\end{array}$ & Naive realism & $\begin{array}{l}\text { Moderate-third-person opportunity } \\
\text { is considered to be readily } \\
\text { identifiable }\end{array}$ \\
\hline Kirzner & $\begin{array}{l}\text { Addressed-primarily } \\
\text { in terms of the } \\
\text { attention stage }\end{array}$ & Relatively ignored & Critical realism & $\begin{array}{l}\text { High-third-person opportunity is } \\
\text { thought to be obscured by market } \\
\text { ignorance }\end{array}$ \\
\hline Knight & $\begin{array}{l}\text { Addressed-primarily } \\
\text { in terms of the } \\
\text { evaluation } \\
\text { stage }\end{array}$ & $\begin{array}{l}\text { Addressed-primarily } \\
\text { in terms of the } \\
\text { evaluation } \\
\text { stage }\end{array}$ & Critical realism & $\begin{array}{l}\text { Low-awareness of third-person } \\
\text { opportunity is taken for granted }\end{array}$ \\
\hline
\end{tabular}

ing theoretical insights that are not ontologically constrained.

\section{REINTERPRETATION OF INFLUENTIAL THEORIES OF THE ENTREPRENEUR}

Failure to address entrepreneurial action in terms of both knowledge and motivation has produced a number of theories of the entrepreneur that are incomplete when used at the individual level of analysis. In this section we use our conceptual model of entrepreneurial action to address possible limitations of the three theories of the entrepreneur that are considered most influential in the management literature: Schumpeter (1934), Kirzner (1973), and Knight (1921). ${ }^{7}$

\section{Schumpeter's Innovator: Epistemological and Ontological Issues}

Schumpeter's theory introduces two major assumptions. The first is that perceived uncertainty does not play a role in entrepreneurial

\footnotetext{
${ }^{7}$ We have chosen to emphasize these three theorists over others for the following reasons. First, as Stevenson and Jarillo (1990) point out, Schumpeter's conceptualization of the entrepreneur has provided one of the primary theoretical foundations on which entrepreneurial management research has been built. Second, Kirzner's conceptualization of the entrepreneur is the most influential in the opportunity paradigm proposed by Shane and Venkataraman (2000) in their recent but already highly influential piece. Finally, Knight was chosen to round off our examples because his theory is typically recognized as the third primary and distinctly original theory of the entrepreneur (Barreto, 1989; Hebert \& Link, 1988).
}

action. This assumption is derived from a belief that opportunity is abundant and readily identifiable. For example, Schumpeter discusses the economy as if it were a relatively closed system that merely interfaces with science, literature, politics, and so forth via the entrepreneur. ${ }^{8}$ In doing so, Schumpeter suggests that opportunities originate elsewhere for all prospective entrepreneurs to see. Because all of the prospective entrepreneurs are equally capable of seeing the development, it is only the adventurous who make the leap-that is, entrepreneurs can be discriminated from others only in terms of the location of their criterion. Schumpeter is then forced to speculate about individual differences in the motivation to act entrepreneurially, and he identifies a number of "traits," including greater self-centeredness (1934: 91-92), "the dream and the will to found a private kingdom"

\footnotetext{
${ }^{8}$ For example, Schumpeter notes:

It is no part of [the entrepreneur's] function to "find" or to "create" new possibilities. These are always present, abundantly accumulated by all sorts of people. Often they are also generally known and being discussed by scientific or literary writers. In other cases, there is nothing to discover about them, because they are quite obvious. To take an example from political life, it was not at all difficult to see how the social and political conditions of France at the time of Louis XVI could have been improved so as to avoid a breakdown of the ancient regime. Plenty of people as a matter of fact did see it. But nobody was in a position to do it. Now, it is this "doing the thing," without which possibilities are dead, of which the [entrepreneur's] function consists (1934: 88)
} 
(1934: 93), "the will to conquer" (1934: 93), and the "joy of creating" (1934: 93-94).

Schumpeter's second major assumption is that opportunities have an objective existencean argument that communicates a social realist ontology. Ontological assumptions are assumptions concerning the nature of social reality. "[A] social realist ontology presumes that actors are real-natural persons having innate capacities to act so as to secure and protect their interests. ... The environment too is regarded as real: it is out there as a part of the natural world" (Scott, 1995: 50). In contrast, a social constructionist ontology suggests that "individuals do not discover the world and its ways, but collectively invent them. Such invention is not random and arbitrary, but itself arises out of and is informed and constrained by existing social arrangements and beliefs" (Scott, 1995: 50). Because Schumpeter's theory conceptualizes possibilities as existing objectively (i.e., in the form of new technologies observable by all), it not only recognizes the existence of a third-person opportunity but it also equates this third-person opportunity with first-person opportunity in every way except one: the amount of desire people exhibit in deciding whether to exploit it.

Subscription to this social realist ontology, in combination with the elimination of epistemological differences, puts Schumpeter into a bit of a straitjacket. Because everyone in his economy shares the same perceptual acumen, opportunities must be new to everyone, not merely the actor, or else they would already have been exploited. This limits Schumpeter's "true" entrepreneur to the domain of radical innovation. ${ }^{9}$ However, the radicalness of the innovation and even the innovation itself become third-party assessments subject to post hoc andlysis. That is, the degree of innovativeness exhibited is more dependent on a subjective evaluation made by a number of observers after the fact than it is on some objectively definable criteria. Consequently, a priori classification of "radical

\footnotetext{
${ }^{9}$ We use the adjective true because although Schumpeter often used the term entrepreneur to refer to both the pioneer and the subsequent entrants, he considered the pioneer, or "leader," to represent the "true" theoretical entrepreneur responsible for stimulating the system. To avoid the confusion associated with introducing a new term, we thought it best to designate this theoretical profile as the "true" entrepreneur rather than the "leader."
}

innovation" is exceptionally difficult and empirically problematic.

One potential explanation for this difficulty is that action is an individual phenomenon affecting system-level outcomes. Traditionally, theoretical focus has started with the system-level outcome (i.e. radical innovation), and the theorist then looked to the actor(s) to determine the cause. This approach unwittingly imposes the ontological assumptions common to economic, system-level theories on to the process experienced by the individual actor (i.e., entrepreneur). Unlike these system-level theories, which rely on an observer's assessment of whether an actor is engaging in radical innovation or bearing uncertainty, a theory of individual action frequently defines novelty through the eyes of the actor (see Weber 1947, 1968) and argues that it is this actor's assessment of the situation that ultimately determines whether entrepreneurial action will occur. Thus, the individual action that impacts the system depends on whether on activity is radical, uncertain, novel, and so forth in the mind of the prospective actor. If this action occurs on a scientific knowledge frontier, then it will likely appear radical to observers, but if this action occurs on a personal knowledge frontier (e.g., franchising), then it may appear to observers to be nothing more than imitation. To the particular actor, however, it may be novel either way. An embrace of this first-person approach is characteristic of the Austrian school and of Kirzner's theory, to which we now turn our attention.

\section{Kirzner's Alert Arbitrageur: Motivational and Configural Issues}

Whereas Schumpeter's entrepreneur disrupts equilibrium by introducing radical innovation, Kirzner's entrepreneur begins in disequilibrium and fulfills the function of an arbitrageur who moves the economy toward equilibrium by rectifying discrepancies in supply and demand. ${ }^{10}$ Unlike Schumpeter, Kirzner (1973) provides ample attention to epistemological differences under the guise of entrepreneurial alertness. However, within Kirzner's (1979) work, there is an

\footnotetext{
${ }^{10}$ These discrepancies in supply and demand are not limited to existing products and services. They also include future discrepancies that can arise from discoveries of superior means-end frameworks of which people were previously unaware.
} 
unwitting dilution of his concept of entrepreneurial alertness from a description of a behavior that is necessary for the economy to function properly $^{11}$ to a description of a psychological characteristic common to successful entrepreneurs. ${ }^{12}$ We say "unwitting" because Kirzner frequently acknowledges the importance of a statement made by his mentor, Ludwig von Mises: "The economist must never be a specialist. In dealing with any problem he must fix his glance upon the whole system" (Mises, 1949: 69).

As a behavior that is necessary for the economy to function properly, entrepreneurial alertness is what happens when the market presents a profitable situation that is successfully exploited by an individual who "fits" the necessary profile (Kirzner, 1973, 1980). In essence, entrepreneurial alertness is a less mathematical exposition of probability theory in which the market presents on objective opportunity for someone possessing the necessary knowledge. Entrepreneurial alertness ensures exploitation of this opportunity and consequently perpetuates the market system.

To use an analogy, entrepreneurial alertness is like a radio trivia contest. Although you or I may not know the answer to the trivia question asked by the disc jockey, someone inevitably

\footnotetext{
${ }^{11}$ For example, Kirzner notes:
}

This entrepreneurial alertness is crucial to the market process. Disequilibrium represents a situation of widespread market ignorance. This ignorance is responsible for the emergence of profitable opportunities. Entrepreneurial alertness exploits these opportunities when others pass them by. G.L.S. Shackle and Lachman emphasized the unpredictability of human knowledge, and, indeed, we do not clearly understand how entrepreneurs get their flashes of superior foresight. We cannot explain how some men discover what is around the corner before others do.... As an empirical matter, however, opportunities do tend to be perceived and exploited. And it is on this observed tendency that our belief in a determinate market process is founded (1979: 9).

${ }^{12}$ For example, within the same book providing the previous comment, Kirzner states:

The truth is that the ability to learn without deliberate search is a gift individuals enjoy in quite different degrees. It is this gift surely, that we have in mind when we talk of entrepreneurial alertness. Entrepreneurial alertness consists, after all, in the ability to notice without search opportunities that have been hitherto overlooked (1979: 148). does. Therefore, an objective opportunity can be said to exist. The first individual who knows the answer and calls in to claim the prize is the exhibitor of Kirzner's (1973) concept of entrepreneurial alertness. Accordingly, entrepreneurial alertness has no meaning a priori. By definition, it can only be said to exist post hoc. Therefore, alertness can only be said to exist for the successful radio caller (and possibly to a lesser degree for those who know the answer, try to call, but are not as fast as the winner). The caller who gets through but provides the wrong answer cannot be described as exercising entrepreneurial alertness. Thus, entrepreneurial alertness is a configural concept in which an objective market opportunity is only an opportunity for those possessing the necessary attributes. Therefore, because this alertness is a product of the market, it is problematic for it to be discussed as a universal attribute of entrepreneurial individuals independent of the system in which they operate.

However, entrepreneurial alertness is used as a description of a psychological characteristic common to successful entrepreneurs in Kirzner's later works (1982, 1997, 1999; Kirzner \& Institute of Economic Affairs, 1997) as an effort to soften (1982: 156-157) the more deterministic stances taken in his earlier work (e.g., 1979: 9). In doing so, he obfuscates the configural nature of the "alertness" concept by discussing it more in terms of a quality observable in characteristics such as prescience, boldness, self-confidence, creativity, and innovative ability (Kirzner, 1999). This transforms entrepreneurial alertness into nothing more than judgment and leads the reader to believe that the concept is separable from the market context. However, we argue that it is not. This judgment is still discussed in terms of how well the entrepreneur's envisaged future corresponds to the realized future (Kirzner, 1982: 156).

The problem that this introduces lies in the fact that Kirzner equates opportunity recognition with entrepreneurial action (e.g., "entrepreneurial alertness exploits these opportunities when others pass them by"-see footnote 11). In a subsequent article in which he compares and contrasts his entrepreneur with Schumpeter's, Kirzner (1999) comes closer to recognizing the need for a criterion. However, he still tries to address motivation in terms of perception (i.e., the proposed solution is still the need for $a$ 
tighter distribution around the mean of the third-person opportunity). Kirzner explicates:

The seer who can imagine how the world might be improved by a radical innovation but who lacks the needed boldness and initiative (to shoulder the risks which he would have to assume in order actually to introduce this innovation to reality in a world fraught with uncertainties)-has in fact not yet really discovered an available, attractive opportunity for innovation. If he has not seen that opportunity in so shining a light that it drives him to its implementation in spite of the jeering skepticism of others, and in spite of the possibility of its ultimate failurethen he has not really "seen" that opportunity (1999 13).

In essence, Kirzner's argumentation collapses the attention and the evaluation stages of our conceptual model of entrepreneurial action into one simultaneous occurrence in which individuals become entrepreneurs if and only if their prior knowledge enables them to go from ignorance to near certainty instantaneously. That is, an individual becomes an entrepreneur when his or her distribution around the third-person opportunity mean is so tight that uncertainty is, for all material purposes, eliminated from the question of whether to act (as was the case in the aforementioned radio contest analogy). The primary problem with this conception lies in the realization that you or I may frequently know the answer to a radio trivia question without believing that the prize is motivating enough to waste time on the unlikely prospect of getting through to the station. Therefore, without motivation, entrepreneurial alertness cannot be expected to produce entrepreneurial action, regardless of how "clearly" one may have "seen" an opportunity.

For the most part, Kirzner's theory of entrepreneurial alertness is an elegant explanation of the attention stage. Ignorance is addressed in terms of perception, and the ability to notice opportunities without search is highly reminiscent of personal strategy. However, to be a theory of the entrepreneur, both the attention and the evaluation stages are necessary. After all, entrepreneurial perception can only be considered "entrepreneurial" when it produces action. This cannot be achieved without evaluating action-specific uncertainty (even if only briefly, owing to a potentially nominal amount of uncertainty). This evaluation, in turn, involves the necessary motivation in relation to one's belief and corresponding doubt that one knows what to do. Therefore, according to Kirzner, being an entrepreneur logically implies that entrepreneurial alertness has been exercised. Without entrepreneurial alertness, the individual would not have perceived and acted on the opportunity, and would not, therefore, be an entrepreneur.

\section{Knight's Uncertainty Bearer: Attention Issues}

Because it emphasizes uncertainty in the explanation of profit, Knight's (1921) theory comes the closest of the three in recognizing the significance of both knowledge and motivation in entrepreneurial action. However, because the context of the theory is an existing firm, the existence of a decision scenario is frequently taken for granted, and little explanation is given to how the decision maker escapes ignorance. Knight argues that individuals frequently face uncertainty in the decisions they make regarding the normal functioning of the enterprisethat is, forecasting consumer demand, projecting costs, and so on. Thus, recognizing or creating opportunities is made insignificant, because profit is believed to come from uncertainty, which Knight considers to be rarely in short supply. Instead, he places emphasis on the responsibility associated with decision making.

Accordingly, Knight's theory discusses entrepreneurial action solely in terms of the evaluation stage, without adequate concern for the attention stage. In other words, there is no need to address the kind of radical uncertainty (i.e., flat response curves) indicative of market ignorance if one begins with the assumption that the stimulus will be thrust on the individual in the normal course of business activities. This position makes Knight's theory congenial to discussions of scanning and deliberate search common to strategy research (Dutton \& Jackson, 1987, 1997) but incomplete when addressing discussions of discovery, which are more commonly associated with entrepreneurship. Because scanning and deliberate search are prompted by a conscious awareness of a need for more information, they address uncertainty and known ignorance (i.e., "I know what it is that I don't know"). Discovery, however, is based on notions of complete ignorance (i.e., "I don't know what it is that I don't know"). That is, the individual is not consciously investigating the phenomenon and may even be 
involved in alternative activities that engage his or her attention, thereby preventing recognition of a third-person opportunity.

Although in some respects Knight's theory offers a less comprehensive explanation of why the economy functions effectively and why firms emerge than either Schumpeter's or Kirzner's, in other ways Knight may have an advantage over Schumpeter and Kirzner. By not discussing the economy explicitly, Knight is able to focus more clearly on the individual's decision-making process. This focus on the individual and relative neglect of the system may be responsible not only for preventing oversight of either knowledge or motivation but also for keeping Knight from becoming too enslaved by his ontological assumptions. Although Knight clearly exhibits social realist sympathies when he suggests that "a man's judgment has, in an effective sense, a true or objective value" (1921: 270-271 footnote), his theory is not constrained by them, as is the case with Schumpeter and Kirzner, each of whom focuses substantially on the concept of equilibrium and disequilibrium.

As a result, Knight's theory is less configural in nature. In fact, the third-person opportunity could be conceptualized in terms of a socially constructed situation in the future about which the entrepreneur must try to accurately predict what will take place. For example, the question is not whether this is or is not an objective opportunity to seize; rather, it is "How firmly do I believe that I can sell a certain number of my new product to the market?" In such a scenario, the expectation becomes the third-person opportunity and the actor's knowledge and motivation contribute to whether the actor deems the scenario action worthy (i.e., "Can I make the future what I want it to be?"). This kind of scenario generation and enactment escapes the heavy determinism implied by the equilibrium paradigm and begins to look a lot like the psychological stances taken by radical, subjectivist economists (e.g., Ebeling, 1986; Maki, 2001; Shackle, 1972) and critical psychologists, such as Weick (1979, 1995). This change in argumentation, however, results in a shift in one's ontological assumptions.

Schumpeter and Kirzner embrace social realism. In both theories discovery plays a role. Because Kirzner begins with a dynamic and inclusive economy, he must address discovery directly, which he does through his concept of market ignorance. Schumpeter also addresses discovery, but more indirectly. He simply pushes it back into the realm of science, making the scientists the inventors and the entrepreneurs merely innovators. However, the fact remains that "discovery" still occurs somewhere in his world view.

In contrast, action theorists of a sociological (DiMaggio \& Powell, 1983; Meyer \& Rowan, 1977) and critical psychological bent (Burke \& Reitzes, 1991; Weick, 1993) favor a social constructionist orientation (Scott, 1995), shying away from terms such as discovery when discussing social contexts (Scott, 1995). These theorists do not see the social environment as something to be discovered; instead, they view it as either "wider belief systems and cultural frames [that] are imposed on or adopted by individual actors and organizations" (Scott, 1995: 44) or as "understandings and scripts [that] emerge out of actions as well as guide them" (Scott, 1995: 45), respectively. This subtle but powerful shift of ontology from social realism to social constructionism presents possibilities and problems for entrepreneurship research.

\section{IMPLICATIONS OF AN ACTION FRAMEWORK}

It is not our purpose in this article to act as proponents or critics of social realism or social constructionism. Rather, we merely wish to illustrate that the many economic theories of the entrepreneur that are so influential to management theory today are, at their core, theories of action that are laden with ontological assumptions. These assumptions influence not only which components of action are discussed but also the way that opportunity is conceptualized. Recognition of this fact enables scholars to draw from these theories in a more productive manner, both theoretically and empirically.

We propose that an action framework can lead to more productive discussions regarding the important entrepreneurial concept of opportunity (Brown, Davidsson, \& Wiklund, 2001; Shane \& Venkataraman, 2000; Stevenson \& Gumpert, 1985). Shane and Venkataraman (2000) draw from economic theory and present an eloquent argument for the objective existence of opportunities. In a highly original study, Shane (2000) pushes this paradigm to the empirical front by establishing the mediating role that prior knowledge has in both the discovery and 
exploitation of opportunity. Perhaps what is most interesting about this study, in relation to our argument, is that the same term opportunity is used to denote both the third-person opportunity of the new technology and the first-person opportunity of the various individuals who perceive it in different ways. For example, Shane states, "Potential entrepreneurs should look to discover opportunities in what they know rather than in what is popular with other entrepreneurs" (2000: 467). Language such as this conveys a belief in the objectivity of third-person opportunity, even if epistemological differences produce different interpretations of it. ${ }^{13}$

Other entrepreneurship scholars who have exhibited a qualified subscription to this paradigm have provocatively proposed the use of signal detection theory (MacMillan \& Creelman, 1991; McFall \& Treat, 1999; Swets, 1996) for examining opportunity recognition and evaluation (e.g., Baron, 2002; McMullen \& Shepherd, 2003). However, the question of whether an error of commission is attributable to entrepreneurial error in terms of misperceived opportunity, poor strategy formulation, poor strategy implementation, or unfavorable changes in environmental conditions becomes, at best, difficult to determine using this ontological foundation.

In stark contrast to these social realists are action enthusiasts who exhibit social constructionist sympathies. For example, Gartner, Carter, and Hills (2001) argue that opportunities are often enacted phenomena with no existence independent of the individuals who envision and/or exploit them. For these scholars, discussion of third-person opportunity undermines their world view. They fear that the language that accompanies this realist ontology reflects an artificially constructed framework superimposed on the phenomenon by scholars to help them make sense of it. They suggest that the consequence of such a framework is that it obfuscates scholarly understanding of the phenomenon as it actually occurs. For example, by using words in surveys such as "discovery." which they argue are not used by people when confronting the phenomenon in a natural state,

\footnotetext{
${ }^{13}$ This suggests that Shane subscribes to a social realist ontology, but it is a "critical realism," in which there are limits on individuals' epistemological abilities, versus a "naive realism," in which no such limitations exist (Lincoln \& Guba, 2000).
}

scholars distort findings by introducing their own conceptions of the phenomenon to be explained. Although the debate regarding which ontology is more suited to entrepreneurship research is integral to "good" science (Cannella \& Paetzold, 1994), it remains diluted as a discussion of the nature of opportunity and unrecognized for what it is-a philosophical debate about the nature of the social world and human action (Burrell \& Morgan, 1979).

Therefore, the primary difference between entrepreneurship scholars with social realist sympathies and those with social constructionist sympathies concerns the nature of third-person opportunity. Is an "opportunity" conceived to be "out there" awaiting discovery, evaluation, and exploitation? Or does one begin with on individual's knowledge and motivation and attempt to determine how that influences his or her mental representation of the environment? We propose two potential approaches for reconciling these contrasting views: one pragmatic and the other conceptual.

\section{A Pragmatic Approach}

Perhaps the easiest way to address the philosophical nature of third-person opportunity is to avoid it. Arguably, this is precisely what many positivist psychologists, such as Simon, Tversky and Kahneman, and Giegerenzer, have done. Using experimental methods or controlled tasks, the researcher is able to observe individual behavior within an "objective," somewhat microcosmic reality. For example, both Simon's work using the game of chess or Tversky and Kahneman's framing experiments examine judgment and decision making regarding an "objective" answer (i.e., one that is logically right or wrong). Historically, the quality of the individual's decision has been determined by equating "good" judgment with "rational" judgment as determined by statistics, or probability theory (Hastie, 2001). Accordingly, these tasks are not subject to multiple interpretations.

This same approach can be used to analyze the decision of whether to engage in entrepreneurial action. Because one can control within an experiment the amount of information presented to the individual, the researcher can control the distance between the noise and thirdperson opportunity means in such a way as to ensure substantial distance or close proximity. 
Thus, regardless of whether an "opportunity" in the real world ever objectively exists, one can create an experiment in which an opportunistic situation does undoubtedly exist (i.e., the potential for arbitrage).

However, such an experiment suffers from some of the critiques leveraged against Knight's theory above (i.e., a decision scenario is forced on the decision maker, leaving the researcher uninformed about the allocation of entrepreneurial attention). In addition, whether a situation can be classified as an opportunity if an individual recognizes it and deems it unworthy of exploitation, and whether an arbitrage opportunity is an "entrepreneurial" opportunity, are questions that require theoretical answers that would most likely go unaddressed under this approach.

One final observation regarding this solution is that it is not so much behavioral as it is cognitive or decisional in nature. Sarasvathy's $(2001 a, b)$ work on effectuation within a slightly more natural setting epitomizes the promising potential of this method. By using "think-aloud" protocols to examine how entrepreneurs think about opportunity, she successfully sidesteps the configural issues that are often embedded in economic theories of the entrepreneur. In fact, the importance of ontological assumptions is effectively eliminated by focusing only on perceived behavioral control and not the actual behavioral control associated with subsequent action. This obviates the need to worry about whether it was the opportunity, the execution, or the environment that prevented successful entrepreneurial action. This approach works well if one is interested in the cognitive elements of opportunity, which is Sarasvathy's objective. However, its extension to action explanation requires one to determine whether the findings on how entrepreneurs think they would go about acting entrepreneurially correspond to how they actually behave under natural circumstances. ${ }^{14}$

\footnotetext{
${ }^{14}$ In the more problematic context of a natural setting scholars have investigated the role of knowledge in entrepreneurship by using measures of general and specific human capital. General human capital typically is operationalized by years of schooling (Rauch \& Frese, 2000; see, for example, Bates, 1995; Evans \& Leighton, 1989; and Davidsson \& Honig, 2003). In the entrepreneurship literature, the most frequently investigated aspect of specific human capital is previous start-up experience (Bates, 1995; Cooper, Folta, \&
}

\section{A Conceptual Approach}

Given these various observations, we propose a conditional compromise that is consistent with an action framework and that includes economic theories of the entrepreneur but is not exclusive to their ontological assumptions. We argue that the willingness to bear the perceived uncertainty associated with an entrepreneurial act is representative of a belief-desire configuration, in which belief of what to do is a function of knowledge and desire of why to do it is a function of motivation. This conceptualization is identical to an intention as described in the context of action theory. For instance, Greve notes:

Actions are distinguished from other kinds of human behavior by the way people usually explain how they came about: They have reasons for actions. This means that individuals do what they do because they desire (want) to reach a goal and believe (expect) that the action is an appropriate or necessary means of reaching it. The beliefs and desires "rationalize" the action (Davidson, 1980a) (Greve, 2001: 437).

Given a specific action, the presence of a specific intention (belief-desire configuration) cannot be doubted. When an observed behavior is in fact the expression of a certain action, then a corresponding intention (constellation of desires and beliefs) is necessarily implied; the hypothesis that this action expresses these particular desires and beliefs cannot be disproven by empirical means. The assertion that a person, when he or she performs an action, does so due to certain beliefs (expectations) and desires (values) is trivially true, because whatever he or she performs would not, in any other case, be an action (Greve, 2001: 439).

Greve suggests that action, by definition, is intentional behavior. Therefore, one cannot start with the behavioral portion of the action and argue that increases in the intention caused the action. This would be tautological, given that the action partially consists of the intention. However, one could avoid tautology by starting with the strength of the intention and predicting whether the intended behavior subsequently ensues. Such an approach to entrepreneurial action would equate the concept of opportunity with that of intention. This action approach (in which the researcher examines the composition of the prospective entrepreneur's intention as it

Woo, 1995; Davidsson \& Honig, 2003; Wright, Robbie, \& Ennew, 1997). 
forms and then determines whether subsequent behavior occurs ${ }^{15}$ ) avoids the tautology inherent in some entrepreneurial studies, the erroneous ascriptions of risk tolerance or superior innovative abilities made by observers, and the post hoc rationalization common to retrospection bias.

In addition, paradigm wars regarding ontological assumptions become less important because, regardless of whether social environments are objective or subjective phenomena, the impact they have on individuals' intentions are real just the same. Therefore, it seems that the ontological concerns discussed in this article only come to the forefront when one is interested in what accounts for the origination of the intention or the quality of the outcome produced by the entrepreneurial action. Thus, it appears that although the study of entrepreneurial action consists of an empirically tractable center capable of paradigmatic reconciliation, entrepreneurial action is "bookended" by two philosophically intractable positions grounded in metaphysical assumption. Whereas for the realist these bookends consist of opportunity recognition and accuracy, for the constructionist they represent the origination of intention and whether individuals can realistically impose their will on any system.

\section{CONCLUSION}

We began this article with an examination of the role that uncertainty plays in economic theories of the entrepreneur. After establishing the need to consider knowledge and motivation concomitantly when examining entrepreneurial action, we proposed a two-stage conceptual model of entrepreneurial action, built on these two constructs and consisting of an attention stage focused on the assessment of third-person opportunity (a possible opportunity for someone) and an evaluation stage focused on the assessment of first-person opportunity (a possible opportunity for the actor). We then used this model to illustrate the conceptual limitations of using system-wide theories of the entrepreneur at the individual level of analysis by reinterpreting

\footnotetext{
${ }^{15}$ See Chattopadhyay, Glick, and Huber (2001) for an excellent example where they employ longitudinal analysis to examine the effect that perception has on subsequent action at the organizational level.
}

three economic theories considered highly influential to managerial thought on the subject of entrepreneurial action. Following this, we discussed how the recognition that these theories of the entrepreneur are theories of action, laden with ontological assumptions about the social world, highlights the need for greater scholarly attention to both knowledge and motivation in future theory building and empirical testing. Finally, we offered a pragmatic and a conceptual solution, inspired by an action framework, as a means of sidestepping or acknowledging philosophically intractable areas associated with the examination of entrepreneurial action.

Given the renewed interest in the individual within entrepreneurship research and the importance of the concept of opportunity to the emerging field of entrepreneurship, we believe that scholars who employ these economic theories of the entrepreneur will benefit from a deeper understanding of their predictions, assumptions, limitations, and possibilities. Not only does it appear that an action framework provides this benefit to entrepreneurship, but also we believe that entrepreneurship provides a promising phenomenon to extend scholarly understanding of the economics, psychology, and sociology of human action.

\section{REFERENCES}

Addleson, M. 1995. Equilibrium versus understanding: Towards the restoration of economics as social theory. London: Routledge.

Ajzen, I. 1996a. The direct influence of attitudes on behavior. In P. M. Gollwitzer \& J. A. Bargh (Eds.), The psychology of action: Linking cognition and motivation to behavior: 385-403. New York: Guilford Press.

Ajzen, I. 1996b. The social psychology of decision making. In E. T. Higgins \& A. W. Kruglanski (Eds.), Social psychology: Handbook of basic principles: 297-325. New York: Guilford Press.

Amabile, T. M. 1997. Entrepreneurial creativity through motivational synergy. Journal of Creative Behavior, 31: 1826.

Aristotle. 1987. The Nicomachean ethics. Amherst, NY: Prometheus Books.

Barnard, C. 1968. The functions of the executive. Cambridge, MA: Harvard University Press.

Baron, R. 2002. OB and entrepreneurship: The reciprocal benefits of closer conceptual links. Research in Organizational Behavior, 24: 225-269.

Barreto, H. 1989. The entrepreneur in microeconomic theory: Disappearance and explanation. London \& New York: Routledge. 
Bates, T. 1995. Self-employment entry across industry groups. Journal of Business Venturing, 10: 143-156.

Baumol, W. J. 1996. Entrepreneurship: Productive, unproductive, and destructive. Journal of Business Venturing, 11: 3-22.

Begley, T. M., \& Boyd, D. P. 1987. Psychological characteristics associated with performance in entrepreneurial firms and smaller businesses. Journal of Business Venturing, 2: 79-93.

Brown, T. E., Davidsson, P., \& Wiklund, J. 2001. An operationalization of Stevenson's conceptualization of entrepreneurship as opportunity-based firm behavior. Strategic Management Journal, 22: 953-968.

Bruner, J. S., Goodnow, J. J., \& Austin, G. A. 1956. A study of thinking. New York: Wiley.

Burke, P. J., \& Reitzes, D. C. 1991. The link between identity and role performance. Social Psychology Quarterly, 44: 83-92.

Burrell, G., \& Morgan, G. 1979. Sociological paradigms and organizational analysis. London: Heinemann.

Busenitz, L., \& Barney, J. 1997. Differences between entrepreneurs and managers in large organizations: Biases and heuristics in strategic decision-making. Journal of Business Venturing, 12: 9-30.

Busenitz, L. W. 1996. Research on entrepreneurial alertness. Journal of Small Business Management, 34(4): 35-44.

Cannella, A. A., Jr., \& Paetzold, R. L. 1994. Pfeffer's barriers to the advancement of organizational science: A rejoinder. Academy of Management Review, 19: 331-34l.

Casson, M. 1982. The entrepreneur: An economic theory. Totowa, NJ: Barnes \& Noble Books.

Chattopadhyay, P., Glick, W. H., \& Huber, G. P. 2001. Organizational actions in response to threats and opportunities. Academy of Management Journal, 44: 937-955.

Conrath, D. 1967. Organizational decision-making behavior under varying conditions of uncertainty. Management Science, 13: B487-B500.

Cooper, A. C., Folta, T. B., \& Woo, C. 1995. Entrepreneurial information search. Journal of Business Venturing, 10: 107-120.

Cooper, A. C., Woo, C. A., \& Dunkelberg, W. 1988. Entrepreneurs perceived chances for success. Journal of Business Venturing, 3: 97-108.

Davidson, D. 1980. Actions, reason, and causes. In D. Davidson (Ed.), Essays on actions and events: 3-19. Oxford: Clarendon.

Davidsson, P., \& Honig, B. 2003. The role of social and human capital among nascent entrepreneurs. Journal of Business Venturing, 18: 301-332.

Dewey, J. 1933. How we think. Boston: Heath.

DiMaggio, P. J., \& Powell, W. W. 1983. The iron cage revisited: Institutional isomorphism and collective rationality in organizational fields. American Sociological Review, 48: $147-160$.

Douglas, E., \& Shepherd, D. A. 2000. Entrepreneurship as a utility maximizing response. Journal of Business Venturing, 15: 393-410.

Duncan, R. B. 1972. Characteristics of organizational environments and perceived environmental uncertainties. Administrative Science Quarterly, 17: 313-327.

Dutton, J. E., \& Jackson, S. E. 1987. Categorizing strategic issues: Links to organizational action. Academy of Management Review, 12: 76-90.

Dutton, J. E., \& Jackson, S. E. 1997. Discerning threats and opportunities. Administrative Science Quarterly, 33: 370-387.

Ebeling, R. M. 1986. Towards a hermeneutical economics: Expectations, prices and the role of interpretation in a theory of the market process. In I. M. Kirzner (Ed.) Subjectivism, intelligibility and economic understanding: Essays in honor of Ludwig Lachmann on his eightieth birthday: 39-55. New York: New York University Press.

Evans, D. S., \& Leighton, L. S. 1989. Some empirical aspects of entrepreneurship. American Economic Review, 79: 519535.

Gaglio, C. M., \& Katz, J. 2001. The psychological basis of opportunity identification: Entrepreneurial alertness. Journal of Small Business Economics, 12(2): 95-111.

Gartner, W. B. 1985. A conceptual framework for describing the phenomenon of new venture creation. Academy of Management Review, 10: 696-706.

Gartner, W. B. 1990. What are we talking about when we talk about entrepreneurship? Journal of Business Venturing, 5: 15-29.

Gartner, W. B., Carter, N. M., \& Hills, G. E. 2001. The language of opportunity. Paper presented at the Movements of Entrepreneurship Workshop, Stockholm, Sweden.

Gatewood, E. J., Shaver, K. G., Powers, J. B., \& Gartner, W. B. 2002. The effects of perceived entrepreneurial ability on task performance and expectancy. Entrepreneurship Theory and Practice, 27(2): 187-206.

Gigerenzer, G. 1991. From tools to theories: A heuristic of discovery. Cognitive Psychology, 98: 254-267.

Goldman, A. 1986. Cognition and epistemology. Cambridge, MA: Harvard University Press.

Greve, W. 2001. Traps and gaps in action explanation: Theoretical problems of a psychology of human action. PsYchological Review, 108: 435-451.

Hagen, E. E. 1962. On the theory of social change. Homewood, IL: Dorsey Press.

Hastie, R. 2001. Problems for judgment and decision making. Annual Review of Psychology, 52: 653-683.

Hayek, F. A. 1945. The use of knowledge in society. American Economic Review, 35: 519-530.

Hebert, R. F., \& Link, A. N. 1988. The entrepreneur: Mainstream views and radical critiques (2nd ed.). New York: Praeger.

Higgins, E. T., \& Kruglanski, A. W. 2000. Motivational science: Social and personality perspectives. Philadelphia: Psychology Press. 
Hogarth, R. M. 1987. The psychology of judgment and choice (2nd ed.). San Francisco: Jossey-Bass.

James, W. 2002. The will to believe. In R. P. Wolff (Ed.), Ten great works of philosophy: 549-574. New York: Signet Classic.

Kaish, S., \& Gilad, B. 1991. Characteristics of opportunity searches of entrepreneurs versus executives: Sources, interests, and general alertness. Journal of Business Venturing, 6: 45-61.

Khilstrom, R., \& Laffont, J. 1979. A general equilibrium entrepreneurial theory of firm formation based on risk aversion. Journal of Political Economy, 87: 719-748.

Kilby, P. 1971. Entrepreneurship and economic development. New York: Free Press.

Kirzner, I. M. 1973. Competition and entrepreneurship. Chicago: University of Chicago Press.

Kirzner, I. M. 1979. Perception, opportunity, and profit: Studies in the theory of entrepreneurship. Chicago: University of Chicago Press.

Kirzner, I. M. 1980. The primacy of entrepreneurial discovery. In I. Kirzner, L. Hannah, N. McKendrick, N. Vinson, K. Wickenden, A. Knight, F. McFadzean, P. D. Henderson, D. G. MacRae, \& I. Pearce (Eds.), The prime mover of progress: The entrepreneur in capitalism and socialism: 3-30. London: Institute of Economic Affairs.

Kirzner, I. M. 1982. Uncertainty, discovery, and human action A study of the entrepreneurial profile in the Misesian system. In I. M. Kirzner (Ed.), Method, process, and Austrian economics: 139-159. Washington, DC: Heath.

Kirzner, I. M. 1985. Discovery and the capitalist process. Chicago: University of Chicago Press.

Kirzner, I. M. 1989. Discovery, capitalism, and distributive justice. Chicago: University of Chicago Press.

Kirzner, I. M. 1997. Entrepreneurial discovery and the competitive market process: An Austrian approach. Journal of Economic Literature, 35: 60-85.

Kirzner, I. M. 1999. Creativity and/or alertness: A reconsideration of the Schumpeterian entrepreneur. Review of Austrian Economics, 11: 5-17.

Kirzner, I. M., \& Institute of Economic Affairs. 1997. How markets work: Disequilibrium, entrepreneurship and discovery. London: Institute of Economic Affairs.

Knight, F. H. 1921. Risk, uncertainty and profit. Washington, DC: Beard Books.

Kunkel, J. H. 1965. Values and behavior in economic development. Economic Development and Cultural Change, 4: 257-277.

Lincoln, Y. S., \& Guba, E. G. 2000. Paradigmatic controversies, contradictions and emerging confluences. In N. Denzin \& Y. Lincoln (Eds.), Handbook of qualitative research (2nd ed.): 163-188. Thousand Oaks, CA: Sage.

Lipshitz, R., \& Strauss, O. 1997. Coping with uncertainty: A naturalistic decision-making analysis. Organizational Behavior and Human Decision Processes, 69: 149-163.

Lumpkin, G. T., \& Dess, G. G. 1996. Clarifying the entrepre- neurial orientation construct and linking it to performance. Academy of Management Review, 21: 135-172.

MacCrimmon, K. R., \& Wehrung, D. A. 1986. Taking risks. New York: Free Press.

MacMillan, N. A., \& Creelman, C. D. 1991. Detection theory: A user's guide. Cambridge: Cambridge University Press.

Maki, U. 2001. The economic world view: Studies in the ontology of economics. Cambridge: Cambridge University Press.

Mann, R. 1996. Antimarket economics: Blind logic, better science, and the diversity of economic competition. Westport, CT: Praeger.

March, J. C. 1981. Decisions in organizations and theories of choice. In A. Van de Ven \& W. F. Joyce (Eds.), Perspectives on organization design and behavior: 205-244. New York: Wiley.

March, J. C., \& Olsen, J. P. 1976. Ambiguity and choice in organizations. Bergen: Universitetsforlaget.

McClelland, D. C. 1961. The achieving society. Princeton, NJ: Van Nostrand.

McFall, R. M., \& Treat, T. A. 1999. Quantifying the information value of clinical assessments with signal detection theory. Annual Review of Psychology, 50: 215-241.

McMullen, J. S., \& Shepherd, D. A. 2003. Extending the theory of the entrepreneur using a signal detection framework. In J. Katz \& D. Shepherd (Eds.), Advances in entrepreneurship, firm emergence, and growth, vol. 6: 203-248. Greenwich, CT: JAI Press.

Menger, C. 1950. Principles of economics. (Translated by J. Dingwall \& B. F. Hoselitz.) Glencoe, IL: Free Press.

Meyer, J. W., \& Rowan, B. 1977. Institutionalized organizations: Formal structure as myth and ceremony. American Journal of Sociology, 83: 340-363.

Milliken, F. J. 1987. Three types of perceived uncertainty about the environment: State, effect, and response uncertainty. Academy of Management Review, 12: 133-143.

Mises, L. V. 1949. Human action: $A$ treatise on economics (4th revised ed.). San Francisco: Fox \& Wilkes.

Moya, C. J. 1990. The philosophy of action: An introduction. Cambridge: Polity Press.

Neufeldt, V., \& Sparks, A. N. (Eds.). 1995. Webster's new world compact school and office dictionary. New York: Wiley.

Palich, L., \& Bagby, R. 1995. Using cognitive theory to explain entrepreneurial risk-taking: Challenging conventional wisdom. Journal of Business Venturing, 10: 425-438.

Pasour, E. C., Jr. 1989. The efficient-markets hypothesis and entrepreneurship. Review of Austrian Economics, 3: 95108.

Rauch, A., \& Frese, M. 2000. Human capital of small scale business owners and business success: A longitudinal study of moderators and mediators. Paper presented at the ICSB World Conference 2000, Brisbane.

Sarasvathy, S. D. 200la. Causation and effectuation: Toward $\alpha$ theoretical shift from economic inevitability to entrepreneurial contingency. Academy of Management Review, 26: 243-288. 
Sarasvathy, S. D. 2001b. Effectual reasoning and entrepreneurial decision making: Existence and bounds. Paper presented at the annual meeting of the Academy of Management, Washington, DC.

Schumpeter, J. A. 1934. The theory of economic development. New Brunswick, NJ: Transaction.

Schumpeter, J. A. 1942. Capitalism, socialism and democracy. New York: Harper Torchbooks.

Scott, W. R. 1995. Institutions and organizations. Thousand Oaks, CA: Sage.

Shackle, G. L. S. 1966. The nature of economic thought: Selected papers 1955-1964. Cambridge: Cambridge University Press

Shackle, G. L. S. 1972. Epistemics and economics: A critique of economic doctrines. New Brunswick, NJ: Transaction.

Shane, S. 2000. Prior knowledge and the discovery of entrepreneurial opportunities. Organization Science, 11: 448469.

Shane, S., \& Venkataraman, S. 2000. The promise of entrepreneurship as a field of research. Academy of Management Review, 25: 217-226.

Shaver, K. G., \& Scott, L. R. 1991. Person, process, choice: The psychology of new venture creation. Entrepreneurship Theory and Practice, 16(2): 23-45.

Smith, K., \& DiGregorio, D. 2002. Bisociation, discovery and the role of entrepreneurial action. In M. Hitt, R. D. Ireland, S. M. Camp, D. Sexton, R. D. Nixon, \& C. E. Lucier (Eds.), Strategic entrepreneurship: Creating a new mindset: 129-150. Malden, MA: Blackwell.

Smithson, M. 1989. Ignorance and uncertainty: Emerging paradigms. New York: Springer-Verlag.

Stevenson, H. H., \& Gumpert, D. 1985. The heart of entrepreneurship. Harvard Business Review, 63(2): 85-94.

Stevenson, H. H., \& Jarillo, J. C. 1990. A paradigm of entre- preneurship: Entrepreneurial management. Strategic Management Journal, 11: 17-27.

Stigler, G. J. 1963. Capital and rates of return in manufacturing industries. Princeton, NJ: Princeton University Press.

Swets, J. A. 1996. Signal detection theory and ROC analysis in psychological diagnostics: Collected papers. Mahwah, NJ: Lawrence Erlbaum Associates.

Taylor, R. N. 1984. Behavioral decision making. Glenview, IL: Scott Foresman.

Terreberry, S. 1968. The evolution of organizational environments. Administrative Science Quarterly, 12: 589-613.

Weber, M. 1930. The Protestant ethic and the spirit of capitalism. New York: Harper Collins.

Weber, M. 1947. The theory of social economic organization. New York: Free Press.

Weber, M. 1968. (First published in 1924). Economy and society: An interpretive sociology. New York: Bedminister.

Weick, K. E. 1979. The social psychology of organizing (2nd ed.). Reading, MA: Addison-Wesley.

Weick, K. E. 1993. Sensemaking in organizations: Small structures with large consequences. In J. K. Murnighan (Ed.), Social psychology in organizations: Advances in theory and research: 10-37. Englewood Cliffs, NJ: Prentice-Hall.

Weick, K. E. 1995. Sensemaking in organizations. Thousand Oaks, CA: Sage.

Whetten, D. A. 1989. What constitutes a theoretical contribution? Academy of Management Review, 14: 490-495.

Wright, M., Robbie, K., \& Ennew, C. 1997. Venture capitalists and serial entrepreneurs. Journal of Business Venturing, 12: 227-249.

Yates, J. F., \& Stone, E. R. 1992. The risk construct. In J. F. Yates (Ed.), Risk-taking behavior: 1-26. New York: Wiley.

Jeffery S. McMullen is an assistant professor of management and entrepreneurship at the Hankamer School of Business, Baylor University. He received his Ph.D. and M.B.A. from the University of Colorado. His research interests include the contextual determinants of entrepreneurial cognition and action, self-regulation, institutional economics, and opportunity.

Dean A. Shepherd is a dean's research fellow and associate professor of entrepreneurship and strategy at the Kelley School of Business, Indiana University. He received his Ph.D. and M.B.A. from Bond University (Australia). His research interests include the decision making of entrepreneurs and their stakeholders, new venture strategy/growth, opportunity, and failure. 